\title{
Pendampingan Penggunaan Layanan Sistem Informasi Berbasis Web Menggunakan Bahasa Pemrograman PHP dan MYSQL
}

\author{
Supriadi ${ }^{1}$, Ilzam Masykuri², Hidayatur Rahman³ ${ }^{3}$ Rahmat Hidayatullah4, \\ Fatahillah Mahendra ${ }^{5}$
}

Universitas Nurul Jadid, Probolinggo 1, 2, 3, 4, 5

\{supriadi@unuja.ac.id1, ilzammasykuri26@gmail.com2,2017hidayaturrahman@gmail.com3, rahmadhidayatullah29091991@gmail.com4, crysismql@gmail.com $\left.{ }^{5}\right\}$

\begin{tabular}{|c|c|}
\hline Submission: 2021 & Published: 2021-04-30 \\
\hline $\begin{array}{l}\text { Keywords: } \\
\text { Information } \\
\text { Systems, } \\
\text { Exams, } \\
\text { Web, PHP, MYSQL }\end{array}$ & $\begin{array}{l}\text { Abstract. Exams are one way to evaluate the learning process. In } \\
\text { the world of education, examinations are intended to measure the } \\
\text { level of achievement of a teaching goal by students, so that } \\
\text { students can find out their level of ability in understanding the field } \\
\text { of study that is being pursued. At SMK Nurur Rahmah, the UAS and } \\
\text { UTS exams have not been done online. The exam process is carried } \\
\text { out by distributing questions that have been printed on a sheet of } \\
\text { paper, then answering them together within } 1 \text { hour. With an exam } \\
\text { system like this one often has problems, such as the habit of } \\
\text { cheating, the slow process of making questions, errors in assessing } \\
\text { exam results, slow preparation of exam results reports. The waste } \\
\text { of paper and ink costs in making questions and multiplying } \\
\text { questions is also one of the problems. The solution to overcome this } \\
\text { problem is to design a computerized system, namely designing a } \\
\text { web-based online exam system. The purpose of this research is to } \\
\text { make it easierfor teachers to make questions, save money and time } \\
\text { in the assessment process and make reports easily. As well as saving } \\
\text { costs in making questions and multiplying exam questions. From } \\
\text { the research results achieved in the form of a web-based } \\
\text { application system using the programming language PHP and } \\
\text { MysQL. which helps make it easier to get data, because in MAN } 1 \\
\text { Probolinggo, in the exam, the students still input data manually. So } \\
\text { that students still have to contact the teachertofind out the process } \\
\text { of test scores has been or has not been completed. And also the } \\
\text { scoring system that is not yet regular. So that the value entered is } \\
\text { not known thoroughly or controlled. }\end{array}$ \\
\hline
\end{tabular}

Katakunci:

Sistem Informasi,

Ujian,

Web,

PHP,

MYSQL

\begin{abstract}
Abstrak. Ujian merupakan salah satu cara untuk mengevaluasi proses belajar. Dalam dunia pendidikan ujian dimaksudkan untuk mengukur taraf pencapaian suatu tujuan pengajaran oleh siswa, sehingga siswa dapat mengetahui tingkat kemampuannya dalam memahami bidang studi yang sedang ditempuh. Pada SMK Nurur Rahmah, ujian UAS dan UTS belum dilakukan secara online. Proses ujian dilakukan dengan membagikan soal yang telah di cetak pada selembaran kertas, kemudian menjawab dengan bersama dalam
\end{abstract}


waktu 1 jam. Dengan sistem ujian yang seperti ini sering kali mempunyai kendala, seperti kebiasaan mencontek, lambatnya proses pembuatan soal, kesalahan dalam menilai hasil ujian, lambatnya pembuatan laporan hasil ujian. Pemborosan biaya kertas dan tinta dalam pembuatan soal dan penggandaan soal juga salah satu masalah. Solusi untuk mengatasi masalah tersebut adalah dengan merancang sebuah sistem yang sudah terkomputerisasi yaitu perancangan sistem ujian online berbasis web. Tujuan Penelitian ini mempermudah guru untuk membuat soal, menghemat biaya dan waktu dalam proses penilaian dan membuat laporan dengan mudah. Serta menghemat biaya daam pembuatan soal dan penggandaan soal ujian. Dari hasil penelitian yang dicapai berupa sistem aplikasi berbasis web menggunakan bahasa pemrograman PHP dan MySQL. yang membantu mempermudah mendapatkan data, karena di MAN 1 Probolinggo dalam ujian masih input data manual terhadap siswanya. Sehingga siswa masih harus menghubungi guru untuk mengetahui proses nilai ujian sudah atau belum selesai. Dan juga sistem penilaiannya yang belum teratur. Sehingga nilai yang masuk tidak diketahui secara menyeluruh atau terkontrol.

\section{Pendahuluan}

Ujian merupakan salah satu cara untuk mengevaluasi proses belajar. Dalam dunia pendidikan ujian dimaksudkan untuk mengukur taraf pencapaian suatu tujuan pengajaran oleh siswa, sehingga siswa dapat mengetahui tingkat kemampuannya dalam memahami bidang studi yang sedang ditempuh. Sistem pengerjaan ujian sekolah ini dilakukan secara tertulis menggunakan kertas dan terdapat tipe soal yaitu pilihan ganda. Ujian sekolah biasanya terdapat 2 macam ujian yaitu ujian tengah semester dan ujian akhir semester. Oleh karena itu ujian sekolah ini menjadi sebuah bahan evaluasi tentang prestasi dan pencapaian peserta didik yang ada disekolah tersebut. SMK Nurur Rahmah adalah sekolah menengah kejuruan swasta yang berada pada desa Jabung Candi, Kabupaten Probolinggo. Sekolah ini menyediakan dua jurusan, yaitu RPL dan perikanan.

SMK Nurur Rahmah dalam hal ujian hanya dilakukan dengan cara tertulis, dimana terdapat 2 ujian yang dilakukan di SMK tersebut yaitu ujian tengah semester dan ujian akhir semester. Kemudian tipe soal yang diberikan oleh guru yaitu soal pilihan ganda. Pada ujian tengah semester dan ujian akhir semester biasanya menggunakan sistem paket soal tergantung kebijakan guru dan koordinator matapelajaran. Kemudian dalam hal pemeriksaan dan 
penilaiannya dilakukan secara otomatis oleh sistem dan guru hanya tinggal menerima nilai dan hasil koreksi ujian.

Pada sekolah ini, ujian UAS (ujian akhir semeter) dan UTS (ujian tengah semester) belum dilakukan secara online. Proses ujian UAS dan UTS dilakukan dengan membagikan soal yang telah di cetak pada selembaran kertas, kemudian menjawab dengan bersama dalam waktu 1 jam. Dengan sistem ujian yang seperti ini sering kali mempunyai kendala, seperti kebiasaan mencontek, lambatnya proses proses penilaian, dikarnakan peserta ujian yang banyak sehingga dapat menghambat guru dalam memasukan nilai kedalam rekap nilai, kesalahan dalam menilai hasil ujian siswa, terjadinya kesalahan penginputan nilai hasil ujian. Pemborosan biaya kertas dan tinta dalam pembuatan soal dan penggandaan soal menjadi masalah utama.

Solusi untuk mengatasi masalah diatas adalah dengan merancang sebuah sistem yang sudah terkomputerisasi yaitu perancangan sistem informasi ujian online berbasis web. Dengan sistem ini pun mempermudah guru untuk membuat soal, menghemat biaya dan waktu dalam proses penilaian dan membuat rekap nilai ujian dengan mudah. Diharapkan siswa dapat melakukan ujian lebih mudah, serta menghasilkan data yang cepat, tepat, dan akurat.

\section{Metode}

Kerangka penelitihan adalah kumpulan konsep yang tersusun secara sistematis agar tujuan penelitihan yang dilakukan menjadi baik, Kerangka penelitihan ini di bentuk sebelum langkah penelitihan di lakukan, dalam penyelesaian masalah yang akan dibahas. Adapun kerangka kerja penelitian yang digunakan seperti terlihat pada gambar 3.1 : (Saquro \& Assegaff, 2019) 


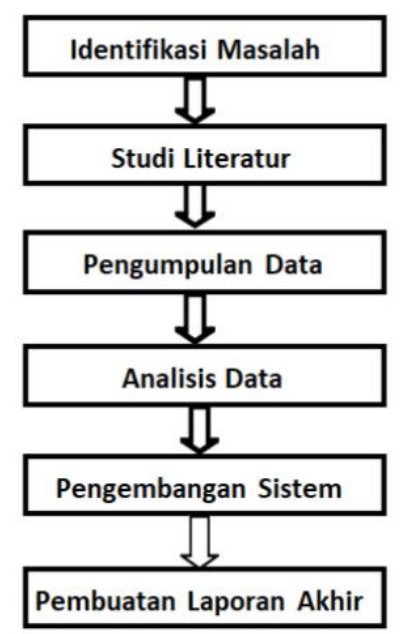

Gambar 1. Alur Penelitian, Sumber (Abdan Saquro, 2019)

Model pengembangan yang digunakan dalam penelitian ini adalah model pengembangan waterfall. Model Waterfall adalah suatu proses pengembangan perangkat lunak berurutan, di mana kemajuan dipandang sebagai terus mengalir ke bawah (seperti air terjun) melewati fase-fase perencanaan, pemodelan, implementasi (konstruksi), dan pengujian. Dalam pengembangannya metode waterfall memiliki beberapa tahapan yang runtut: requirement (analisis kebutuhan), design sistem (system design), Coding \& Testing, Penerapan Program, pemeliharaan (Tristianto, 2018).

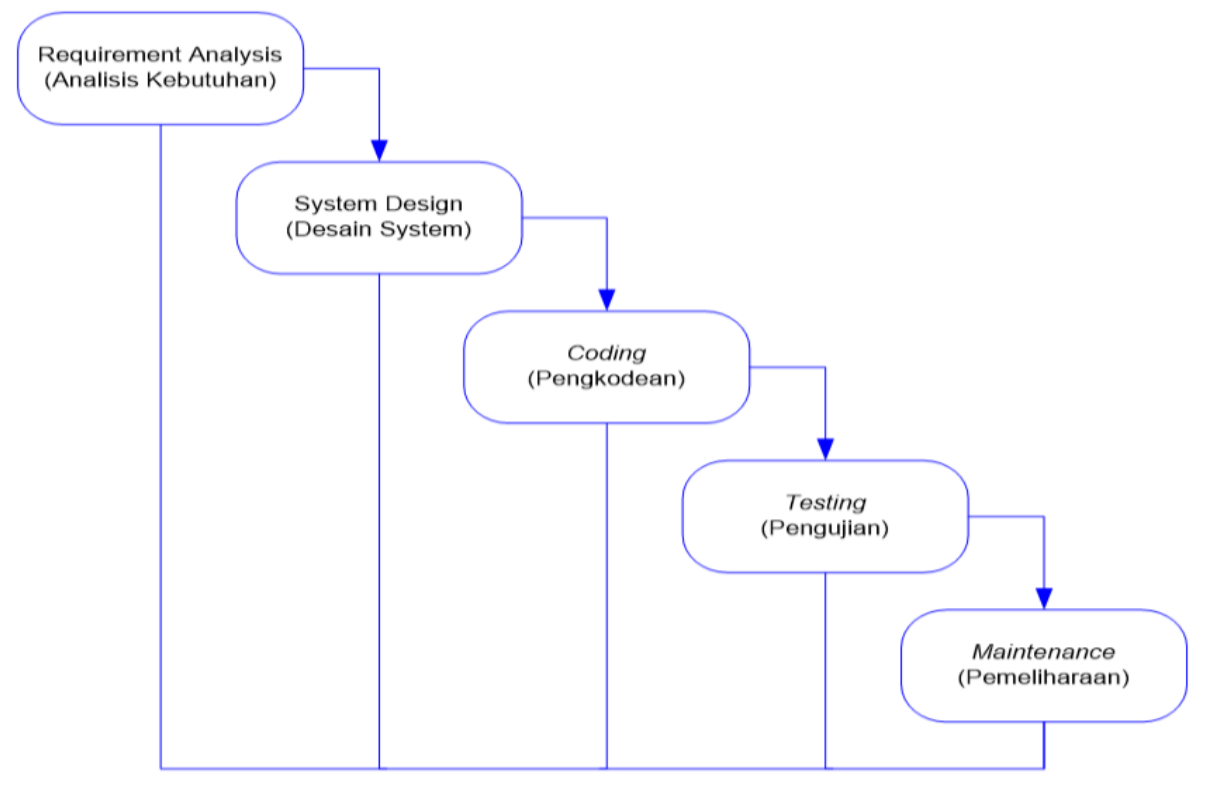

Gambar 2. Model Penelitian \& Pengembangan Waterfall (Tristianto, 2018). 


\section{Hasil}

\section{a. Hasil Pengumpulan Data}

Pada tahap analisis kebutuhan peneliti mengumpulakan data yang dibutuhkan untuk proses perancangan dan pembangunan sistem dengan cara melakukan observasi dan wawancara kepada pihak terkait.

\section{b. Wawancara}

Adapun hasil wawancara yang dilakukan di MAN 1 Probolinggo yaitu sebagai berikut:

Tabel 1. Hasil Wawancara

\begin{tabular}{|c|c|c|}
\hline No & Bagian & Wawancara \\
\hline 1 & $\begin{array}{l}\text { Kepala } \\
\text { Sekolah }\end{array}$ & $\begin{array}{l}\text { Bagaimana sistem ujian di MAN } 1 \text { Probolinggo yang } \\
\text { sudah berjalan? } \\
\text { Seperti ujian pada umumnya, Di MAN } 1 \text { Probolinggo } \\
\text { dalam hal ujian hanya dilakukan dengan cara tertulis, } \\
\text { dimana terdapat } 2 \text { ujian yang dilakukan di SMK tersebut } \\
\text { yaitu ujian tengah semester dan ujian akhir semester. } \\
\text { Kemudian terdapat tipe soal yang diberikan oleh guru } \\
\text { yaitu soal pilihan ganda. Pada ujian tengah semester dan } \\
\text { ujian akhir semester biasanya menggunakan sistem paket } \\
\text { soal tergantung kebijakan guru dan koordinator } \\
\text { matapelajaran. Kemudian dalam hal pemeriksaannya } \\
\text { dilakukan secara manual oleh guru dan penilaiannya } \\
\text { dilakukan secara manual satu persatu. } \\
\text { Bagaimana kemampuan guru dan siswa tentang sistem } \\
\text { informasi? } \\
\text { Semua guru dan siswa mampu mengoperasikan } \\
\text { komputer, memiliki jaringan internet, dan juga di sini } \\
\text { memiliki kualitas sinyal yang bagus. }\end{array}$ \\
\hline 2 & Guru & $\begin{array}{l}\text { Apakah penginputan datanya masih menggunakan kertas } \\
\text { atau manual? } \\
\text { Benar, penginputan, serta pengkoreksiannya masih } \\
\text { dilakukan secara manual. } \\
\text { Bagaimana kemampuan siswa tentang sistem informasi? } \\
\text { Ada juga yang kurang paham teknologi, tetapi mayoritas } \\
\text { siswa adalah orang - orang pelajar yang bisa / paham } \\
\text { smartphone hingga komputer }\end{array}$ \\
\hline
\end{tabular}




\section{Pembahasan}

Data Flow Diagram (DFD) merupakan bentuk diagram yang menggambarkan arus data dalam sebuah Aplikasi. Pemberian pada arus data ini penting karena arus data berkaitan dengan Database, terdapat beberapa level dalam perancangan DFD.Context Diagram merupakan tahapan pertama dalam arus data. Context diagram adalah penggambaran aplikasi pertama secara garis besar (top level) dan di pecah-pecah menjadi bagian terinci. Context Diagram untuk Sistem Informasi Ujian Online Berbasis Web dapat dilihat pada Gambar 4.3

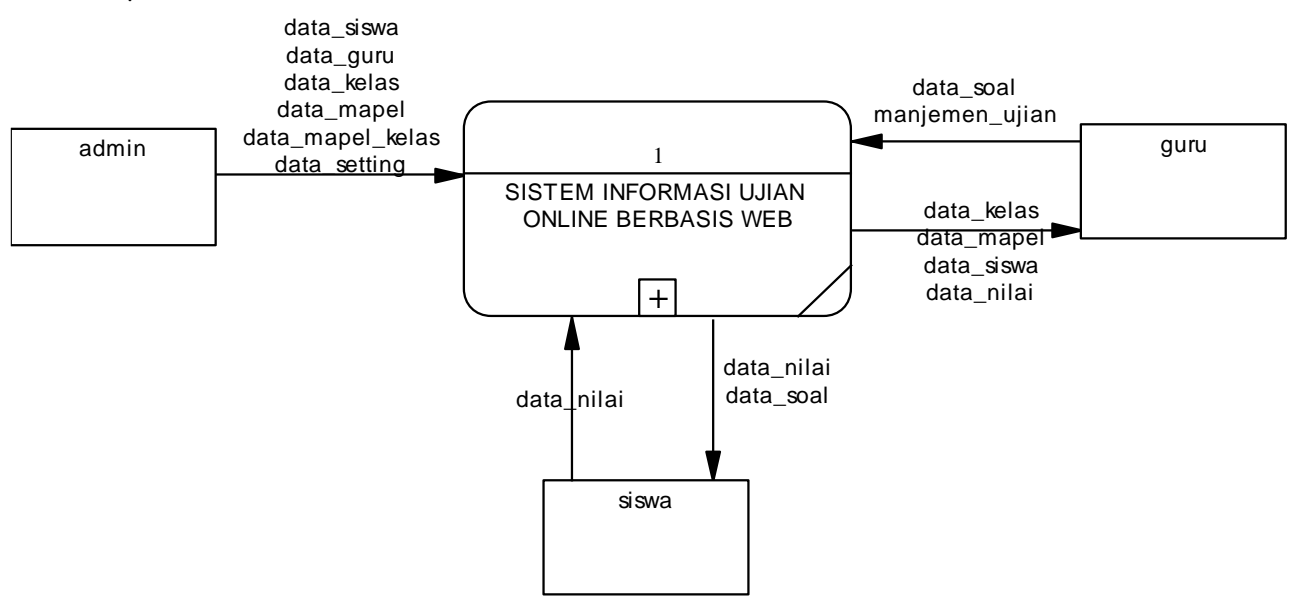

Gambar 3. Contex Diagram

Pada Entity Relationship Diagram (ERD), hubungan antar file direlasikan dengan kunci relasi (Relational Key) yang merupakan kunci utama dari masing masing file. ERD terdiri dari sekumpulan objek dasar, yaitu entitas-entitas yang saling berhubungan Derajat keterhubungan antar entitas pada suatu relasi tersebut dengan kardinalitas.

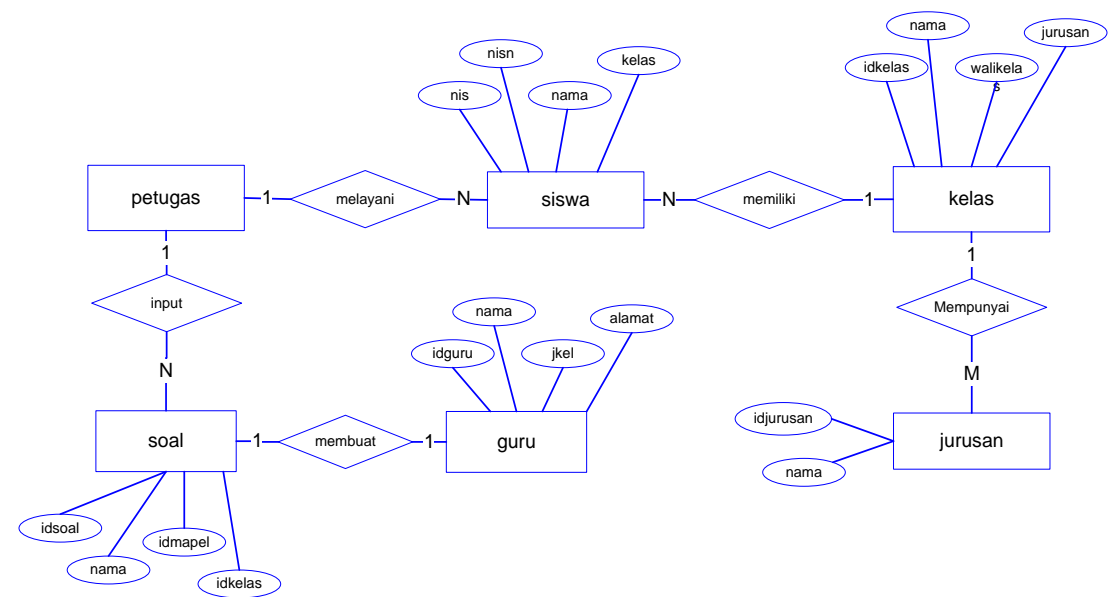

Gambar 4. ERD 
Implementasi dalam Penelitian ini Menggunakan 3 Hak Akses yaitu Admin,Guru dan Siswa/Wali Murid

a. Tampilan Login

Pada halaman login admin akan diminta memasukkan username dan password admin.

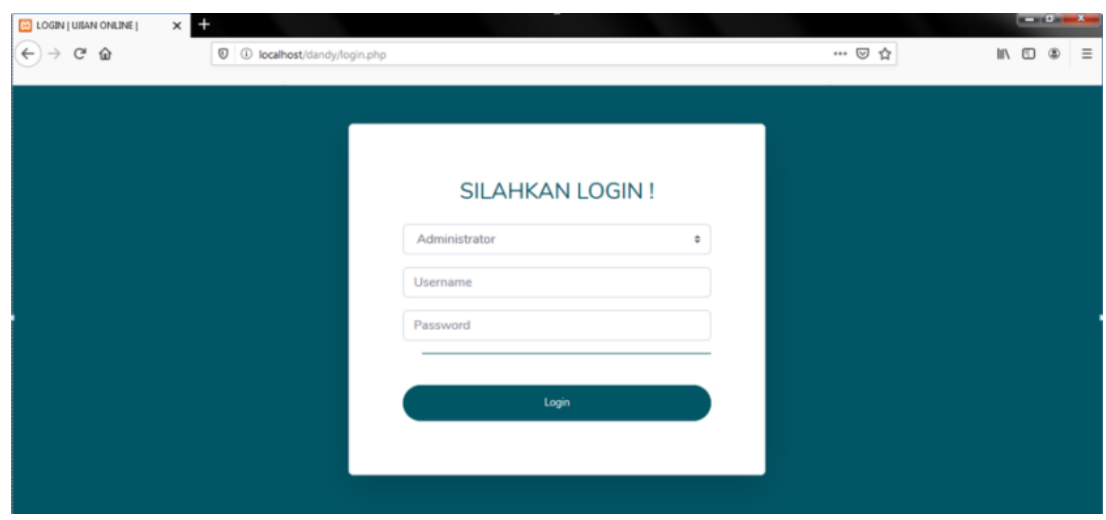

Gambar 5. Tampilan Login

b. Tampilan Home Admin

Pada halaman awal admin terdapat data siswa, data guru, data mapel, data kelas, data jurusan

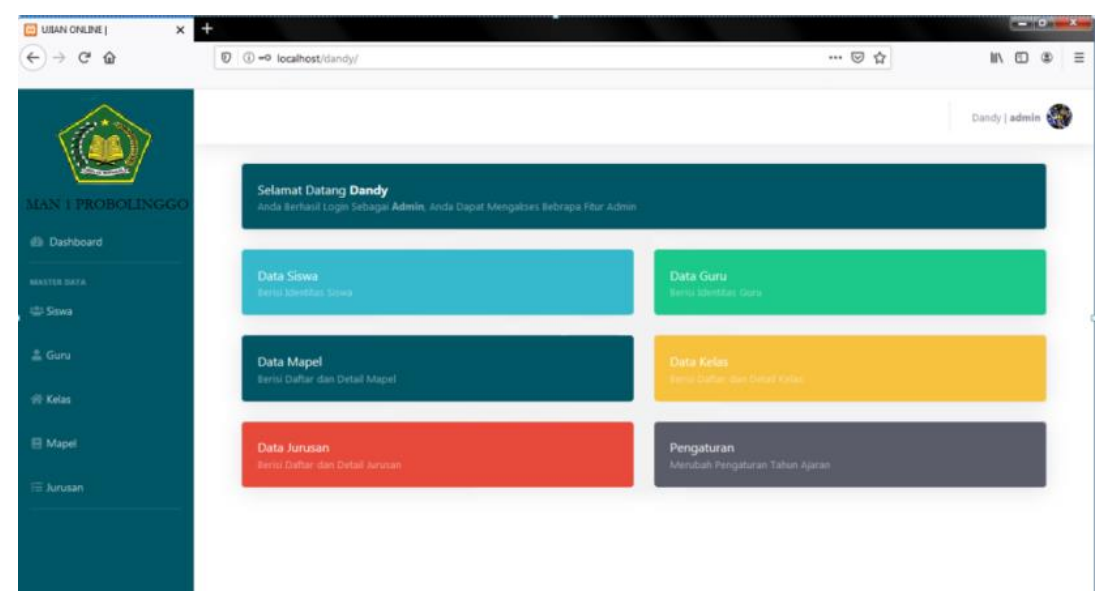

Gambar 6. Tampilan Home Admin 
C. Tampilan Profil

Pada halaman profil, admin dapat mengedit data profil yang ada.

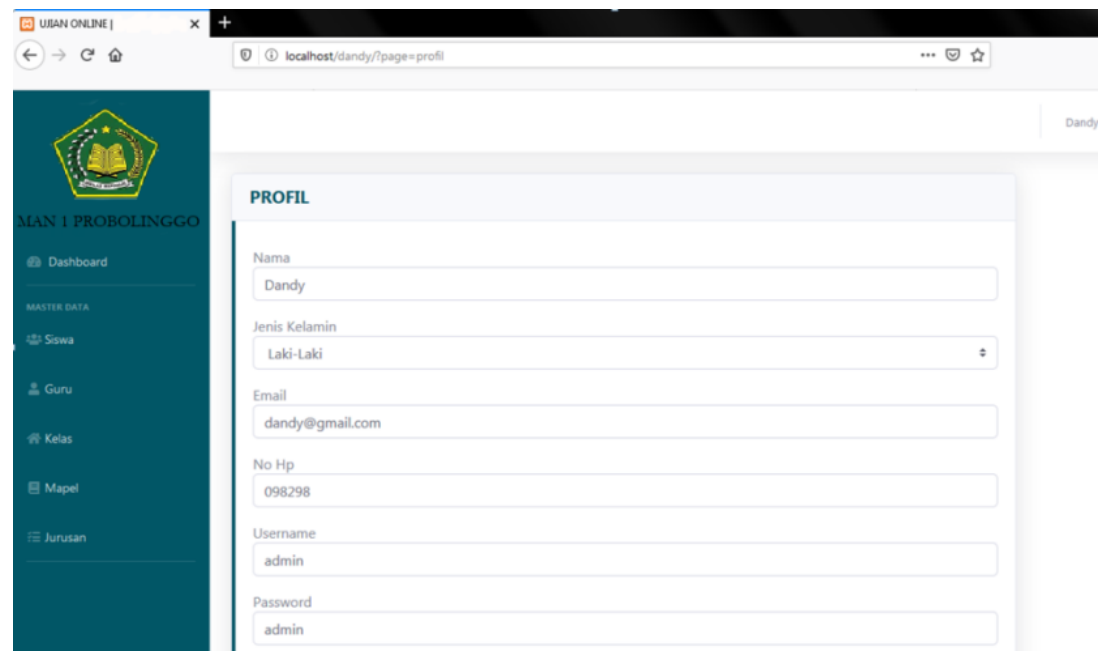

Gambar 6. Tampilan Profile

\section{d. Tampilan Setting}

Pada halaman setting, admin dapat mengganti tahun ajaran.

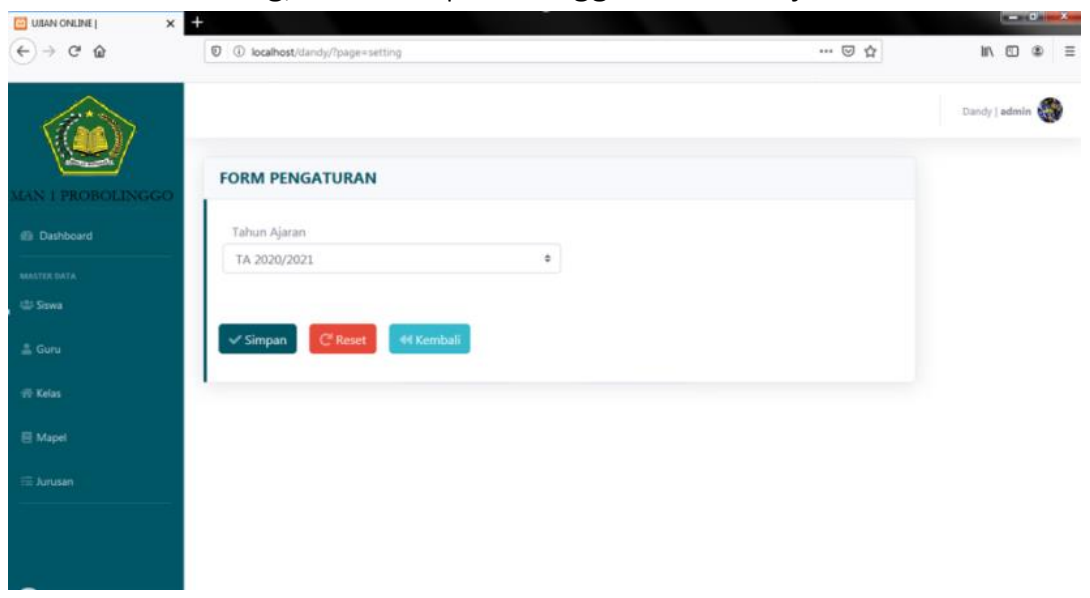

Gambar 7. Halaman Setting 


\section{e. Tampilan Data Siswa}

Pada halaman data siswa, admin dapat menambah, mengedit atau menghapus data siswa yang ada.

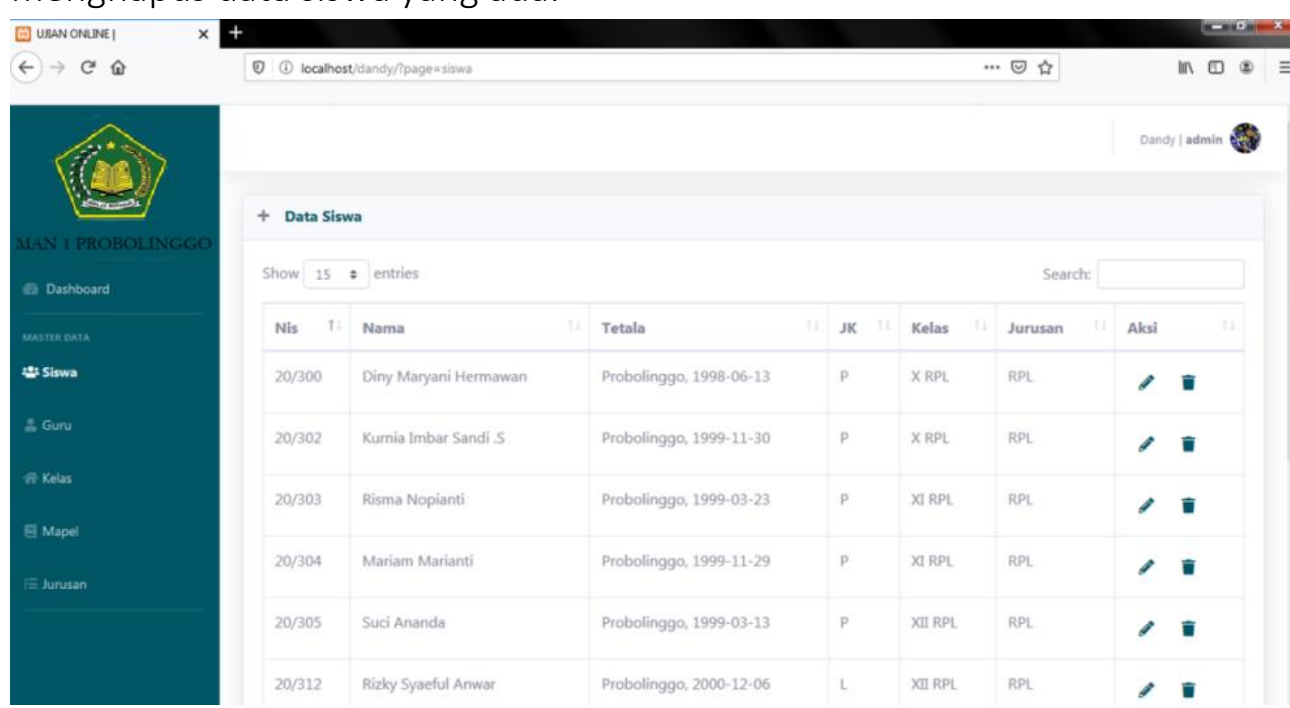

Gambar 8. Halaman Data Siswa

\section{f. Tampilan Data Guru}

Pada halaman data guru, admin juga dapat menambah, mengedit atau menghapus data guru yang ada.

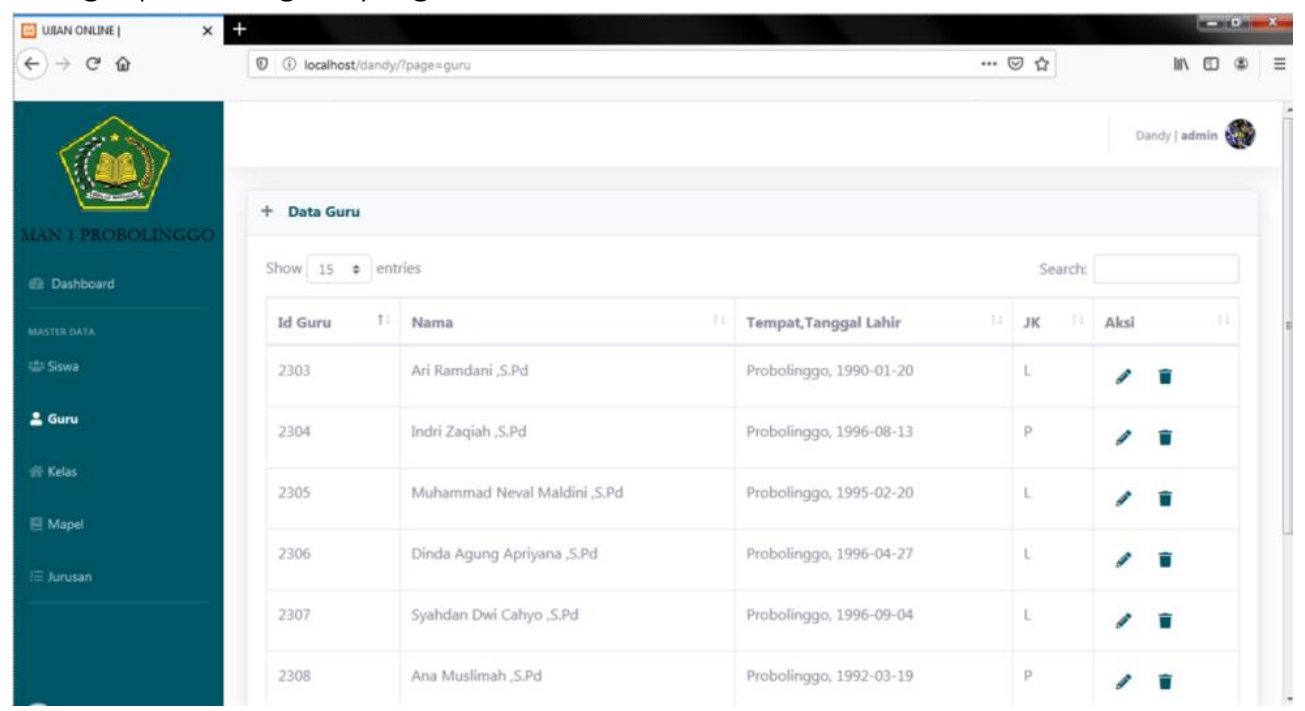

Gambar 9. Halaman Data Guru 
g. Tampilan data kelas

Pada halaman data kelas, admin juga dapat menambah, mengedit atau menghapus data kelas yang ada.

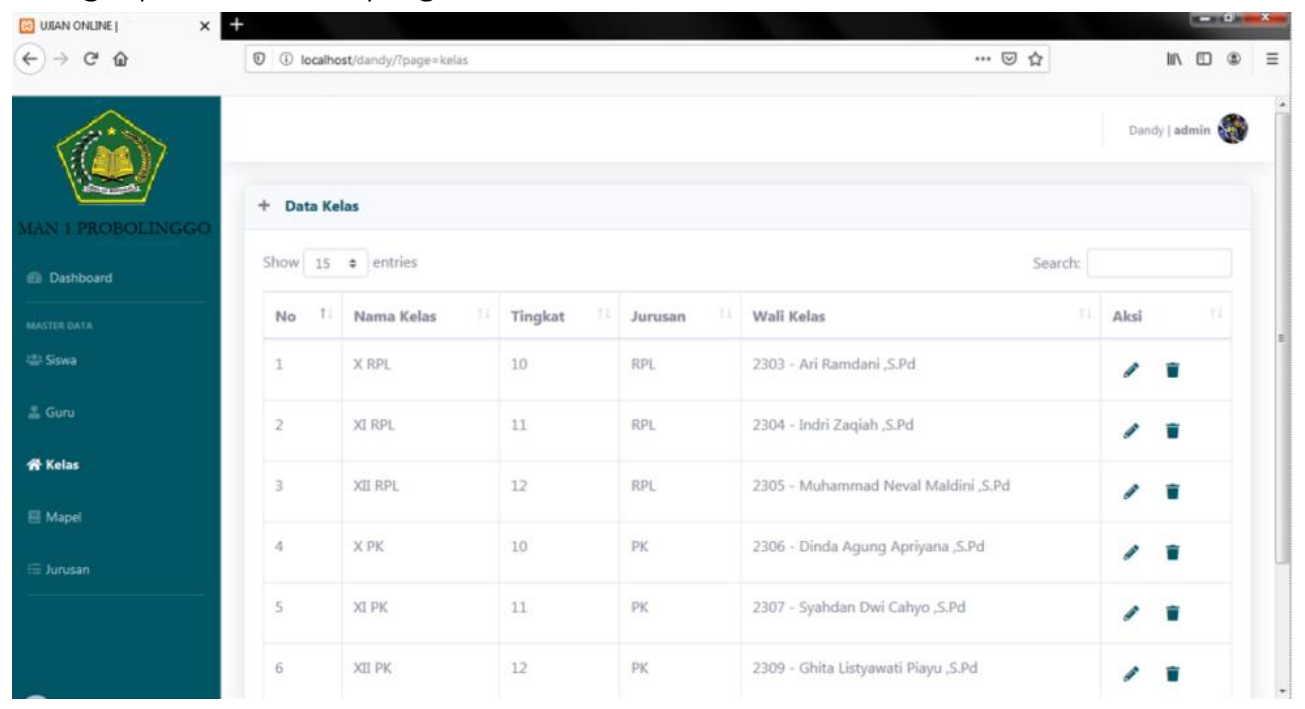

Gambar 10. Halaman Data Kelas

h. Tampilan Data Mapel

Pada halaman data mapel, admin juga dapat menambah, mengedit atau menghapus data mapel yang ada.

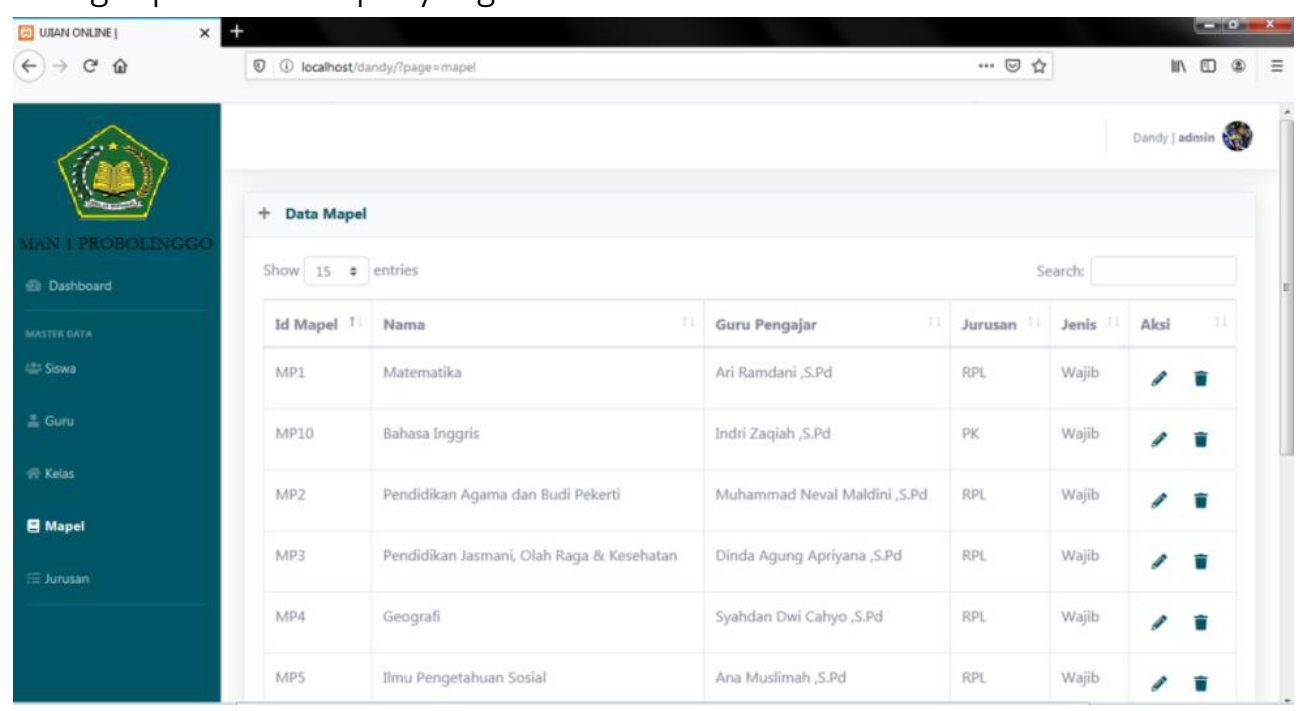

Gambar 11. Halaman Data Mapel 
i. Tampilan Data Jurusan

Pada halaman data jurusan, admin juga dapat menambah, mengedit atau menghapus data jurusan yang ada.

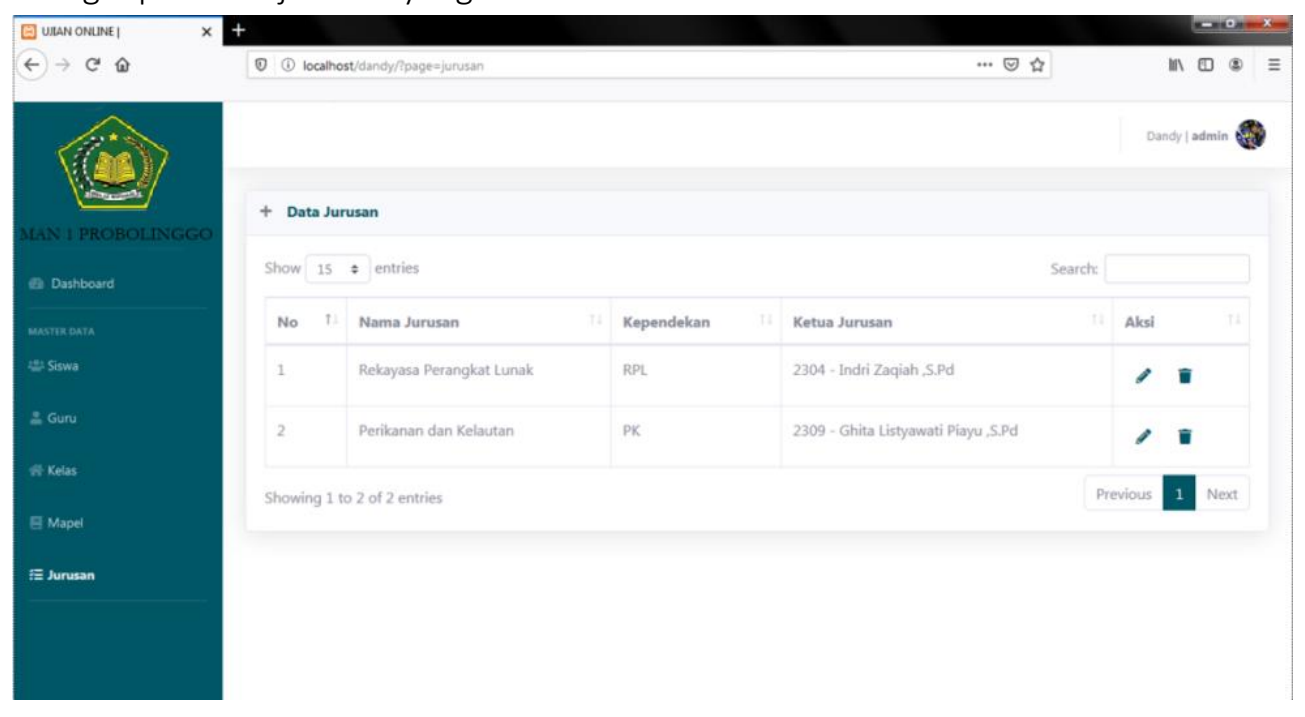

Gambar 12. Halaman Data Jurusan

\section{Kesimpulan}

Berdasarkan hasil penelitian yang telah dilakukan di SMK Nurur Rohmah pada sebuah program aplikasi sistem informasi ujian online, dihasilkan kesimpulan sebagai tujuan dibangunnya sistem informasi ujian online yang berbasis Web di SMK Nurur Rohmah yang nantinya diharapkan mampu untuk meningkatkan pembelajaran bagi para siswa di sekolah tersebut, serta mampu meningkatkan kualitas bagi sistem pembelajaran itu sendiri.

Berikut adalah kesimpulan dari penelitian serta menindak lanjuti rumusan masalah yang telah diuraikan sehingga menjadi seperti dibawah ini:

a. Pada penelitian tugas akhir ini telah menghasilkan aplikasi ujian online.

b. Aplikasi yang dibuat telah memenuhi kriteria dari pihak sekolah dengan menambahkan fitur: acak soal dan menampilkan nilai pada setiap individu.

c. Pada aplikasi dalam hal pemeriksaan dan penilaiannya dilakukan secara otomatis oleh sistem dan guru hanya tinggal menerima nilai dan hasil koreksi ujian. 
Aplikasi yang dibuat bertujuan untuk mempersiapkan siswa dalam menghadapi ujian UTS (Ujian Tengah Semester) dan UAS (Ujian Akhir Semester).

\section{Referensi}

Destiningrum, M., \& Adrian, Q. J. (2017). Sistem Informasi Penjadwalan Dokter Berbassis Web Dengan Menggunakan Framework Codeigniter (Studi Kasus: Rumah Sakit Yukum Medical Centre). Jurnal Teknoinfo, 11(2), 30. https://doi.org/10.33365/jti.v11i2.24

Februariyanti, H. (2012). Rancang Bangun Sistem Perpustakaan untuk Jurnal Elektronik. 17(2), 124-132.

Hidayatun, N. (2013). Kajian Teknologi Sistem Ujian Online. XV(1), 67-79.

Iswandy, E. (2015). Sistem Penunjang Keputusan Untuk Menentukan Dan Santunan Sosial Anak Nagari Dan Penyaluran Bagi Mahasiswa Dan Pelajar Kurang Mampu. Jurnal TEKNOIF, 3(2), 70-79. https://doi.org/2338-2724

Mubarok, A., \& Kurniawan, M. C. (2016). Aplikasi Ujian Online Pada Smk Ma'Arif Bandung Berbasis Web. Jurnal Informatika, 2(1), 332-344. https://doi.org/10.31311/ji.v2i1.89

Muhamad Son Muarie. (2015). Rancang Bangun Sistem Ujian Online Pada Smp Negeri 8 Sekayu. Jurnal Teknik Informatika Politeknik Sekayu (TIPS), 2(1), 28-40.

http://jurnal.polsky.ac.id/index.php/tips/article/view/38

Simargolang, M. Y., Siregar, H. F., \& Nurmala, N. (2018). Aplikasi Pelayanan Jasa Laundry Berbasis WEB. Teknologi Informasi, 2(1), 1.

Susilowati, S., \& Hidayat, T. (2018). Rancang Bangun Sistem Informasi Ujian Online ( Studi Kasus Pada SMAN 58 Jakarta ). Jurnal Teknik Komputer, 4(1), 30-36. https://ejournal.bsi.ac.id/ejurnal/index.php/jtk/article/viewFile/2474 $/ 1902$ 
Saquro, A., \& Assegaff, S. (2019). Informasi Ujian Berbasis Android Pada Smkn 3 Kota Jambi. Analisis Perancangan Aplikasi Sistem Informasi Ujian Berbasis Android Pada SMKN 3 Kota Jambi, 4(3), 276-288.

Tristianto, C. (2018). Penggunaan Metode Waterfall Untuk Pengembangan Sistem Monitoring Dan Evaluasi Pembangunan Pedesaan. Jurnal Teknologi Informasi ESIT, XII(01), 8-22.

Fathansyah. (2012). Basis Data - Buku Teks Ilmu Komputer Basis Data (Edisi Revisi). Informatika : Jakarta

Kristianto, Harianto. (2000). Konsep dan Tuntunan Praktis Basis Data. Andi : Yogyakarta

Jogiyanto, Hartono. (2005). Analisis \& Desain Sistem Informasi Pendekatan Terstruktur Teori dan Praktek Aplikasi Bisnis. Andi : Yogyakarta 